Regards sur l'économie allemande

Bulletin économique du CIRAC

$71 \mid 2005$

Varia

\title{
Compétitivité territoriale
}

RÖHL Klaus-Heiner, Sonderwirtschaftszonen als Instrument der Regionalentwicklung. Neue Ideen für die neuen Bundesländer

\section{(2) OpenEdition}

Journals

Édition électronique

URL : http://journals.openedition.org/rea/350

DOI : $10.4000 /$ rea. 350

ISBN : 978-2-8218-0838-6

ISSN : 1965-0787

Éditeur

CIRAC

Édition imprimée

Date de publication : 1 mai 2005

ISSN : 1156-8992

Référence électronique

«Compétitivité territoriale », Regards sur l'économie allemande [En ligne], 71 | mai 2005, document 2, mis en ligne le 24 avril 2008, consulté le 22 septembre 2020. URL : http://journals.openedition.org/rea/ 350 ; DOI : https://doi.org/10.4000/rea.350

Ce document a été généré automatiquement le 22 septembre 2020

(c) CIRAC 


\section{Compétitivité territoriale}

RÖHL Klaus-Heiner, Sonderwirtschaftszonen als Instrument der Regionalentwicklung. Neue Ideen für die neuen Bundesländer

\section{RÉFÉRENCE}

RÖHL Klaus-Heiner, Sonderwirtschaftszonen als Instrument der

Regionalentwicklung. Neue Ideen für die neuen Bundesländer, IW-Positionen, $\mathrm{n}^{\circ} 10$, Deutscher Instituts-Verlag, Cologne 2004, 56 p.

1 Dans l'actuel débat sur une nécessaire réforme de l'Aufbau Ost (voir dans ce numéro), cet ouvrage apporte une contribution intéressante. La création d'un statut de «zone franche» pour chacun des nouveaux Länder leur permettrait de développer des politiques économiques et sociales innovantes. Leur expérience pourrait aussi à terme se révéler utile pour la poursuite des réformes structurelles dans l'ensemble de l'Allemagne. (ib) 